\title{
Extraintestinal manifestations of inflammatory bowel disease
}

\author{
Inflamatuvar barsak hastalığının ekstraintestinal tutulumu
}

\author{
Ahmet UYANIKOĞLU1', Filiz AKYÜZ², Fatih ERMiş³, Kadir DEMIR², Sadakat ÖZDIL², Fatih BEŞIŞIK², \\ Sabahattin KAYMAKOĞLU², Güngör BOZTAŞ², Zeynel MUNGAN²
}

\author{
Department of ${ }^{1}$ Gastroenterology, Harran University School of Medicine, Şanlıurfa \\ Department of ${ }^{2}$ Gastroenterohepatology, İstanbul University, İstanbul School of Medicine, İstanbul \\ Department of ${ }^{3}$ Gastroenterology, Düzce University School of Medicine, Düzce
}

\begin{abstract}
Background and Aims: The reported frequency of extraintestinal manifestations in inflammatory bowel disease varies from $6 \%$ to $47 \%$. We evaluated extraintestinal manifestations of inflammatory bowel disease patients who were followed up in our clinic. Materials and Methods: The epidemiological findings, disease duration, extraintestinal manifestations, and complications were evaluated between April 1998 and April 2008, retrospectively. Results: Four hundred

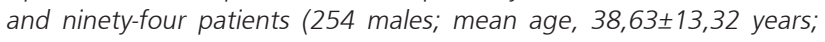
range, 16-78) were evaluated: 283 (57,3\%) with ulcerative colitis, 194 (39,3\%) with Crohn's disease and 17 (3.4\%) with indeterminate colitis. The mean disease duration was 70,66 75,93 months (1-1008

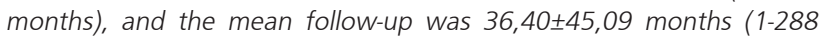
months). The extraintestinal manifestation rate was 19.2\% (95/494) in the whole group, and included arthritis in 32 (6,5\%), hepatobiliary in $13(2,6 \%)$, skin in $13(2,6 \%)$, multiple extraintestinal manifestations in $16(3,2 \%)$, renal calculus in $12(2,4 \%)$, thromboembolic events in 5 (1\%), and eye involvement in $4(0,8 \%)$. Complications were observed in a total of 78 patients $(15,8 \%)$. Complication rates were as follows: 29 $(5,9 \%)$ abscess, 15 (3\%) perforation, 5 (1\%) malignancy, 1 (0,2\%) toxic megacolon, and $15(2,6 \%)$ others. The complication rate was higher in Crohn's disease than ulcerative colitis $(29,3 \%$ vs 3,6\%). There was a positive correlation between extraintestinal manifestations and the complication rate in ulcerative colitis $(p=0,007, r=0,173)$, and a positive correlation was observed between colonic involvement and extraintestinal manifestations in Crohn's disease ( $p=0,04, r=0,144)$. Conclusions: The most common extraintestinal manifestation was arthritis, and the most frequently seen complications were abscess and perforation. The complication rate was higher in Crohn's disease than ulcerative colitis. Extraintestinal manifestations may enhance the complication rate in UC. In Crohn's disease, the extraintestinal manifestations rate is higher in colonic involvement than in ileocolonic and ileal involvement. Colonic involvement in Crohn's disease is a predictive factor for extraintestinal manifestations.
\end{abstract}

Key words: Inflammatory bowel disease, extraintestinal manifestation.

\section{INTRODUCTION}

The etiology of inflammatory bowel disease (IBD) is still unknown. Crohn's disease (CD) and ulcerative colitis (UC) are immune-mediated disorders of unknown etiology that primarily affect the gastrointestinal tract. In addi-
Giriş ve Amaç: Inflamatuvar barsak hastalığında ekstraintestinal bulguların sıklığı \%6-47 olarak bildirilmiştir. Kliniğimizde takip edilen inflamatuvar barsak hastalarında görülen ekstraintestinal bulguları değerlendirdik. Gereç ve Yöntem: Nisan 1998 ve Ocak 2008 arasında takip edilen hastalar ekstraintestinal bulgular, epidemiyolojik veriler, hastalık süreleri, komplikasyonları açısından retrospektif olarak değerlendirildi. Bulgu-

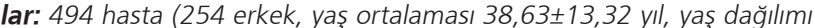
16-78) değerlendirmeye alındı. Bu hastalardan 283'ü $(\% 57,3)$ ülseratif kolit, 194'ü (\%39,3) Crohn hastalı̆̆ı ve 17'si (\%3.4) indetermine kolit idi. Hastalık yaşı ortalama 70,66 75,93 (1-1008) ay idi. Ortalama takip süresi $36,40 \pm 45,09$ ay (1-288 ay) idi. Tüm inflamatuvar barsak hastalarında ekstraintestinal bulguların sıkığı \%19,2 (95/494) olup dağılımı: seronegatif artrit $32(\% 6,5)$, hepatik tutulum $13(\% 2,6)$, deri tutulumu $13(\% 2,6)$, kombine $16(\% 3,2)$, renal kalkül $12(\% 2,4)$, tromboemboli 5 (\%1), göz tutulumu $4(\% 0,8)$ idi. 78 hastada $(\% 15,8)$ komplikasyon görüldü: [29 abse (\%5,9), 15 perforasyon (\%3), 5 malignite (\%1), 1 toksik megakolon $(\% 0,2)$ ve 15 diğer komplikasyonlar $(\% 2,6)]$. Crohn hastalığında komplikasyon oranı ülseratif kolitten fazla idi (\%29,3'e $\% 3,6)$. Ülseratif kolitli hastalarda ekstraintestinal bulgular ile komplikasyon sıklığı arasında $(p=0,007, R=0,173)$, Crohn hastalarında kolonik tutulum ile ekstraintestinal bulgular arasında $(p=0,04, R=0,144)$ pozitif korelasyon tesbit edildi. Sonuç: Inflamatuvar barsak hastalarında en sık ekstraintestinal bulgu seronegatif artrittir. En sık komplikasyon ise abse ve perforasyondur. Ekstraintestinal bulguların varlığı ülseratif kolit seyrinde komplikasyon riskini arttırır. Crohn hastalığında kolonik tutulum, ekstraintestinal bulguların varlığııı gösteren prediktif bir faktördür.

Anahtar kelimeler: Inflamatuvar barsak hastalığı, ekstraintestinal bulgular

tion, other organ systems can be involved, such as joint/ bones, skin, eyes, hepatobiliary tract, lungs, and kidney. Overall, they represent extraintestinal manifestations (EIMs) of IBD, and may present before, in conjunction 
with, or after the onset of bowel disease. Considering the epidemiological, genetic and immunological data, $U C$ and $C D$ are heterogeneous disorders of multifactorial etiology in which hereditary (genetic) and environmental (microbial, behavior) factors interact to produce the disease (1-4). Patients with any of these manifestations have a higher risk of developing another one. EIMs of IBD are prevalent in both $U C$ and $C D(5,6)$.

Inflammatory bowel disease (IBD) is associated with EIMs in approximately $20-40 \%$ of patients $(4,7-10)$. Due to the relative refractoriness of the disease and a possible increase in morbidity and mortality, prompt recognition of extracolonic organ involvement in IBD is important $(11,12)$. IBD is associated with a variety of EIMs that may produce greater morbidity than the underlying intestinal disease and may even be the initial presenting symptoms of the IBD. Some are more commonly related to active colitis (joint, skin, ocular, and oral manifestations). Others are seen especially with small bowel dysfunction (cholelithiasis, nephrolithiasis, and obstructive uropathy), and some are nonspecific disorders (osteoporosis, hepatobiliary disease and amyloidosis) (9).

The most common EIMs affect the joints, skin, eyes, and biliary tract. The successful treatment of EIMs is essential for improving the quality of life of IBD patients (8). EIMs do not change the remission rate, but prolong the time to achieve remission. Perhaps even more important, these extraintestinal symptoms can be the primary manifestation of $C D$ and $U C(13,14)$.

The aim of this study was to evaluate EIMs in IBD patients and the effect of these manifestations on the clinical course.

\section{MATERIALS AND METHODS}

The epidemiological findings, disease duration, EIMs, and complications were evaluated between April 1998 and April 2008 retrospectively. This administrative definition has previously been validated in CD, UC and indeterminate colitis (ID).

In order to investigate EIMs, abdominal ultrasonogra- phy, sacroiliac radiography and eye examination were performed. Intestinal and extraintestinal symptoms and laboratory tests were followed up regularly. Any alteration suggesting an EIM was investigated by a specialist.

The Statistical Package for the Social Sciences (SPSS) 15,0 (Chicago, IL) was used for statistical evaluation. Univariate analyses, correlation matrices and multivariate regression were performed. Further subgroup analyses were performed.

\section{RESULTS}

Totally, 494 IBD patients (254 male, 240 female; mean age, 38,63 $\pm 13,32$ years; range, 16-78) were evaluated retrospectively. Distribution of IBD was as follows: 283 $(57,3 \%) \cup C, 194(39,3 \%) C D$ and 17 (3,4\%) ID.

The mean disease duration was $70,66 \pm 75,93$ months (1-1008 months), and the mean follow-up period was $36,40 \pm 45,09$ months (1-288 months).

The rate of EIMs was $19,2 \%(n=95)$ in the whole group. Distribution of EIMs was as follows: seronegative arthritis $32(6,5 \%)$, hepatobiliary involvement $13(2,6 \%)$, skin involvement $13(2,6 \%)$, multiple EIMs $16(3,2 \%)$, renal calculus $12(2,4 \%)$, thromboemboli $5(1 \%)$, and eye involvement $4(0,8 \%)$ (Figure 1).

The rates of EIMs of CD, UC and ID were $18 \%, 19,1 \%$ and $17,6 \%$, respectively. There was no statistically significant difference between the groups $(p>0,05)$. Thromboembolic events (4/283 vs $1 / 194)$, arthritis (19/283 vs $12 / 194)$, hepatobiliary involvement (8/283 vs 5/194), and renal calculus ( $8 / 283$ vs $2 / 194)$ were higher in UC; however, this difference was not statistically significant. There was also no significant difference between UC and CD patients according to the incidence of ocular $(2 / 283$ vs $2 / 194)$ and skin involvement (7/283 vs 6/194). The rate of multiple EIMs (9/194 vs 7/283) was higher in CD than $U C$, but the difference was not statistically significant $(p>0,05)$.

Rates of EIMs of CD were as follows: seronegative arthritis in $12(6,2 \%)$, hepatobiliary involvement in $5(2,6 \%)$,

\begin{tabular}{|c|c|c|c|c|c|c|c|}
\hline & Arthritis & Multiple EIMs & Hepatobiliary & Skin inv. & $\begin{array}{l}\text { Renal } \\
\text { calculus }\end{array}$ & $\begin{array}{c}\text { Thrombo- } \\
\text { emboli }\end{array}$ & Eye inv. \\
\hline UC & $19(6,7 \%)$ & $7(2,5 \%)$ & $8(2,8 \%)$ & $7(2,5 \%)$ & $8(2,8 \%)$ & $4(1,4 \%)$ & $2(0,7 \%)$ \\
\hline CD & $12(6,2 \%)$ & $9(4,6 \%)$ & $5(2,6 \%)$ & $6(3,1 \%)$ & $2(1 \%)$ & $1(0,5 \%)$ & $2(1 \%)$ \\
\hline ID & $1(5,9 \%)$ & & & & $2(11,8 \%)$ & & \\
\hline Total & $32(6,5 \%)$ & $16(3,2 \%)$ & $13(2,6 \%)$ & $13(2,6 \%)$ & $12(2,4 \%)$ & $5(1 \%)$ & $4(0,8 \%)$ \\
\hline
\end{tabular}

EIMs: Extraintestinal manifestations. UC: Ulcerative colitis. CD: Crohn's disease. ID: Indeterminate colitis. inv: Involvement. 


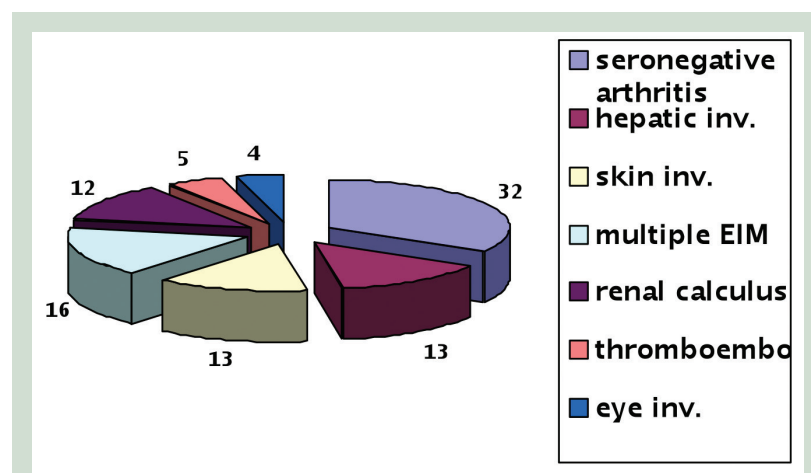

Figure 1. Distribution of EIMs of inflammatory bowel disease (EIM: Extraintestinal manifestation, inv.: Involvement).

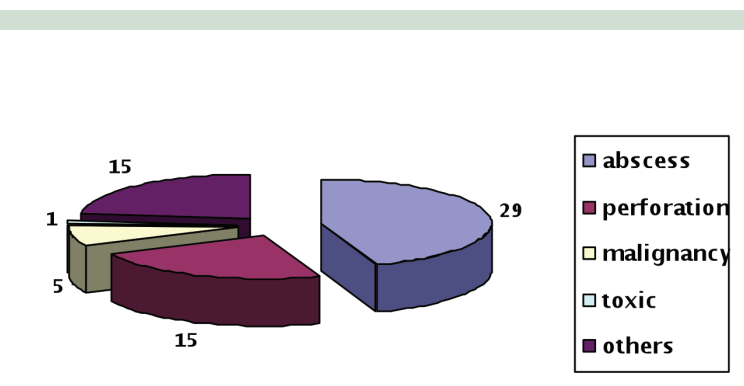

Figure 2. Distribution of complications in inflammatory bowel disease. skin in $6(3,1 \%)$, multiple EIMs in $9(4,6 \%)$, renal calculus in $2(1 \%)$, thromboembolic events in $1(0,5 \%)$, and eye involvement in $2(1 \%)$. Rates of EIMs of UC were as follows: seronegative arthritis in $19(6,7 \%)$, hepatobiliary involvement in $8(2,8 \%)$, skin in $7(2,5 \%)$, multiple EIMs in $7(2,5 \%)$, renal calculus in $8(2,8 \%)$, thromboembolic events in $4(1,4 \%)$, and eye involvement in $2(0,7 \%)$. EIMs of ID were recorded as seronegative arthritis in 1 $(5,9 \%)$ and renal calculus in $2(11,8 \%)$ (Table 1$)$.

Complications were observed in a total of 78 patients $(15,8 \%)$. Complication rates were as follows: 29 (5,9\%) abscess, 15 (3\%) perforation, 5 (1\%) malignancy, 1 $(0,2 \%)$ toxic megacolon, and $15(2,6 \%)$ others (amyloidosis, growth retardation, bowel resection, colectomy, septicemia, demyelinating disease, etc.) (Figure 2).

The complication rates in CD, UC and ID were $29,3 \%$, $3,6 \%$ and $5,9 \%$, respectively. The complication rate in $C D$ was found to be higher than that of UC and ID $(p<0.005)$. Abscess $(27 / 194$ vs $1 / 283)$ and perforation $(14 / 194$ vs $1 / 283)$ rates were significantly higher in $C D$ than UC. There was no significant difference between $C D$ and $U C$ according to the incidence of malignancy (2/194 vs 3/283). One patient with toxic megacolon had ileocolonic CD.

There was a positive correlation between EIMs and the complication rate in UC $(p=0,007, r=0,173)$, and a positive correlation was also observed between colonic involvement and EIMs in $C D(p=0,04, r=0,144)$. EIMs were seen at rates of $10,6 \%$ in ileal, $19,5 \%$ in ileocolonic and $28,6 \%$ in colonic CD.

\section{DISCUSSION}

Inflammatory bowel disease (IBD) is a systemic disease associated with a number of EIMs involving almost every organ in the body. The reported frequencies of EIMs in patients with IBD have varied between $6 \%$ and $47 \%$ (15-
20). Globally, about one-third of patients develop systemic manifestations (10). The true prevalence of the ElMs associated with IBD may vary depending on the geographic area, IBD population, location and duration of the disease, medication, and diagnostic accuracy (1). In our series, the EIM rate was 19,2\% ( $n=95 / 494)$ in the whole group.

In the literature, the rates of EIMs of UC and CD were $5.7 \%$ and $19 \%$, respectively, and of complications in UC and CD were $6,4 \%$ and $50,8 \%$, respectively (21). In our series, EIM rates were similar (CD 18\%, UC 19,1\%, ID $17,6 \%)$, but the complication rate was higher in $C D$ than UC $(29,3 \%$ vs $3,6 \%)$.

Mendoza et al. (16) evaluated 566 patients in a prospective study and showed that joint manifestations were the most common EIM. Hepatobiliary manifestations, venous thromboembolism and arthralgias were more frequent in UC than CD. Erythema nodosum and peripheral arthritis were more frequent in $C D$. The prevalence rates of ocular manifestations and the remaining joint manifestations were not different between UC and CD. Thromboembolic events and hepatobiliary and renal involvement were higher in UC in our study; however, this difference was not statistically significant. There was also no significant difference between CD and UC according to incidence of arthritis and ocular and skin involvement. Multiple EIMs were not statistically significantly higher in CD.

The most common EIMs affect the joints, skin, eyes, and biliary tract $(8,22)$. Seronegative arthritis $(6,5 \%)$, hepatic involvement $(2,6 \%)$ and skin involvement $(2,6 \%)$ were the most common extraintestinal diseases of all groups in our patients. Eye involvement $(0,8 \%)$ was seen less frequently than the others.

The presence of one EIM appears to confer a higher likelihood of developing other manifestations than would be expected by chance alone (9). Multiple EIMs were seen in 16 of our patients. 
In the literature, only $3 \%$ of UC patients required surgery, whereas $27 \%$ of CD patients underwent surgical procedures $(p<0,001)(21)$. Both extraintestinal and local complications were more frequent in $C D$ patients, whereas arthritis was the most common EIM in both diseases (23). We observed complications in a total of 78 patients $(15,8 \%)$.

Familial IBD was associated with the presence of EIMs, while ileal involvement and noninflammatory behavior independently increase the risk of surgery (24). Female gender, steroid dependency and colonic involvement are associated with the risk of developing EIMs of CD (19). In another study, perianal complications alone were found significantly more common in patients with colitis and ileocolitis than in those with disease of small bowel involvement only. There was a significantly positive association between perianal disease and the presence of extraintestinal features (25). We observed a positive correlation between colonic involvement and EIMs in CD $(p=0.04, r=0.144)$. Data regarding the complication rates in IBD and the relation of EIMs are rare in the literature. In our study, there was a positive correlation between EIMs and the complication rate in $U C(p=0.007, r=0.173)$. In conclusion, the most common EIM of IBD was seronegative arthritis, and the most common complications were abscess and perforation. The complication rate was higher in CD than UC. EIMs may enhance the complication rate in UC. The EIM rate in CD was higher in colonic involvement than in ileocolonic and ileal involvement. Colonic involvement in CD is a predictive factor for EIMs.

\section{REFERENCES}

1. Karlinger K, Györke T, Makö E, et al. The epidemiology and the pathogenesis of inflammatory bowel disease. Eur J Radiol 2000; 35: 154-67.

2. Andrisani G, Guidi L, Papa A, Armuzzi A. Anti-TNF alpha therapy in the management of extraintestinal manifestation of inflammatory bowel disease. Eur Rev Med Pharmacol Sci 2012; 16: 890-901.

3. Konduk BT, Hülagü S. İnflamatuvar bağırsak hastalıklarında tanı. Turkiye Klinik J Int Med Sci 2005; 1: 16-53.

4. Agrawal D, Rukkannagari S, Kethu S. Pathogenesis and clinical approach to extraintestinal manifestations of inflammatory bowel disease. Minerva Gastroenterol Dietol 2007; 53: 233-48.

5. Veloso FT, Carvalho J, Magro F. Immune-related systemic manifestations of inflammatory bowel disease. A prospective study of 792 patients. J Clin Gastroenterol 1996; 23: 29-34.

6. Levine JS, Burakoff R. Extraintestinal manifestations of inflammatory bowel disease. Gastroenterol Hepatol 2011; 7: 235-41.

7. Siemanowski B, Regueiro M. Efficacy of infliximab for extraintestinal manifestations of inflammatory bowel disease. Curr Treat Options Gastroenterol 2007; 10: 178-84.

8. Barrie A, Regueiro M. Biologic therapy in the management of extraintestinal manifestations of inflammatory bowel disease. Inflamm Bowel Dis 2007; 13: 1424-9.

9. Ardizzone S, Puttini PS, Cassinotti A, Porro GB. Extraintestinal manifestations of inflammatory bowel disease. Dig Liver Dis 2008; 40 (Suppl 2): S253-9.

10. Veloso FT. Extraintestinal manifestations of inflammatory bowel disease: Do they influence treatment and outcome? World J Gastroenterol 2011; 17: 2702-7.

11. Das KM. Relationship of extraintestinal involvements in inflammatory bowel disease: new insights into autoimmune pathogenesis. Dig Dis Sci 1999; 44: 1-13.

12. Şentürk Ö, Öztürk T, Çelebi A, et al. İnflamatuar barsak hastalığı olan hastaların değerlendirilmesi ve ekstraintestinal manifestasyonlar: Sürmekte olan prospektif çalışmanın ön sonuçları. Turk J Gastroenterol 2010; 21(Suppl 1): S49.

13. Ozdil S, Akyuz F, Pinarbasi B, et al. Ulcerative colitis: analyses of 116 cases (do extraintestinal manifestations affect the time to catch remission?). Hepatogastroenterology 2004; 51: 768-70.

14. Rogler G, Schölmerich J. Extraintestinal manifestations of inflammatory bowel disease. Med Klin (Munich) 2004; 99: 123-30.

15. Kethu SR. Extraintestinal manifestations of inflammatory bowel diseases. J Clin Gastroenterol 2006; 40: 467-75.

16. Mendoza JL, Lana R, Taxonera $C$, et al. Extraintestinal manifestations in inflammatory bowel disease: differences between Crohn's disease and ulcerative colitis. Med Clin (Barc) 2005; 125: 297-300.

17. Bernstein CN, Blanchard JF, Rawsthorne P, Yu N. The prevalence of extraintestinal diseases in inflammatory bowel disease: a population-based study. Am J Gastroenterol 2001; 96: 1116-22.

18. Lakatos L, Pandur T, Dávid G, et al. Extra-intestinal manifestation of IBD in Veszprém county (of Hungary): results of a 25-years followup study. Orv Hetil 2003; 144: 1965-75.

19. Barreiro-de Acosta M, Domínguez-Muñoz JE, Núñez-Pardo de Vera MC, et al. Relationship between clinical features of Crohn's disease and the risk of developing extraintestinal manifestations. Eur J Gastroenterol Hepatol 2007; 19: 73-8.

20. Vavricka SR, Brun L, Ballabeni $P$, et al. Frequency and risk factors for extraintestinal manifestations in the Swiss Inflammatory Bowel Disease Cohort. Am J Gastroenterol 2011; 106: 110-9.

21. Jiang L, Xia B, Li J, et al. Retrospective survey of 452 patients with inflammatory bowel disease in Wuhan city, central China. Inflamm Bowel Dis 2006; 12: 212-7.

22. Tavarela Veloso F. Review article: skin complications associated with inflammatory bowel disease. Aliment Pharmacol Ther 2004; 20 (Suppl 4): 50-3.

23. Tozun N, Atug O, Imeryuz N, et al.; Members of the Turkish IBD Study Group. Clinical characteristics of inflammatory bowel disease in Turkey: a multicenter epidemiologic survey. J Clin Gastroenterol 2009; 43: 51-7.

24. Lakatos PL, Szalay F, Tulassay Z, et al.; Hungarian IBD Study Group. Clinical presentation of Crohn's disease. Association between familial disease, smoking, disease phenotype, extraintestinal manifestations and need for surgery. Hepatogastroenterology 2005; 52: 817-22.

25. Rankin GB, Watts HD, Melnyk CS, Kelley ML Jr. Gastroenterology. National Cooperative Crohn's Disease Study: extraintestinal manifestations and perianal complications. 1979; 77: 914-20. 